\title{
TEISÉ
}

\section{TEISĖKŪRA LIETUVOJE: \\ INSTITUCINIAI IR KULTŪRINIAI \\ PROBLEMŲ SUVOKIMO FRAGMENTAI}

\author{
Dr. Alvidas Lukošaitis
}

Lietuvos Respublikos Seimo kanceliarijos Tyrimu skyriaus vedejas

Office of the Seimas of the Republic of Lithuania

Head of Research Unit

Gedimino pr. 53, LT-01109 Vilnius

El.paštas alvidas.lukosaitis@lrs.lt

\section{Santrauka}

Straipsnyje, remiantis statistiniais duomenimis, supažindinama su teisèkūra ir jos tendencijomis Lietuvoje. Analizuojama teisèkūra parlamento lygmeniu, teigiama, kad dalis teisèkūros problemu kyla dèl nekonstruktyvios šiame procese dalyvaujančiu valdžios instituciju sqveikos ir Seimo nariu požiūrio ị teisèkūros sprendimus. Atkreipiamas demesys, kad sudètingos ir nuolat kintančios laikmečio aplinkybès 1990-2020 metais lèmè pernelyg intensyvia Seimo teisèkūros darbotvarke ir paskatino parlamenta itin aktyviai veikti teisèkūros srityje, kartu ir visos teisinès sistemos nestabilumą. Seimo priimamu teisèkūros sprendimu kokybę neigiamai veikè kompleksinès teisés aktu projektu ekspertizes ignoravimas, nepagristas ir ilgainiui netinkamu įpročiu tapęs išimtiniu teisèkūros taisykliu (skubos ir ypatingos skubos tvarkos) taikymas, perdèm plačiai traktuojama Seimo nariu teisèkūros diskrecija, per mažas dèmesys teisèkūros darbotvarkès planavimui.

Reikšminiai žodžiai: teisèkūra, teisèkūros būklè, teisèkūros darbotvarkè, teisès aktų projektų ekspertizé, skubos ir ypatingos skubos tvarka, teisèkūros diskrecija, teisèkūros darbotvarkès planavimas. 


\section{Teisèkūros bruožai, tendencijos ir problemos}

Lietuvos Respublikos Konstitucinis Teismas yra akcentavęs, kad Seimo, kaip demokratinès tautos atstovybès, funkcijos yra įtvirtinti konstitucines vertybes, o įstatymų leidyba - išskirtinè Seimo prerogatyva, istatymais reguliuojami svarbiausi visuomenès gyvenimo klausimai. ${ }^{1}$ Galbūt tai viena iš priežasčių, kodèl Lietuvos parlamentas teisèkūros srityje yra išskirtinai aktyvi institucija. Tai patvirtina ilgamečiai statistiniai duomenys, taip pat ir lyginamieji tarptautiniai, kuriais remdamiesi galime teigti, kad šiuo aspektu mūsų Seimas išskirtinis visoje Europoje. ${ }^{2}$ I tokị Seimo aktyvumą bei su tuo susijusias teisèkūros problemas audito ataskaitoje yra atkreipusi dèmesị ir Valstybès kontrole. ${ }^{3}$

Per tą laiką, kai Lietuva vèl nepriklausoma, Seime užregistruojama ir priimama vis daugiau įstatymų ir kitų teisès aktų projektų. 20082012 m. Seimo kadencijoje jų užregistruota daugiau nei 5 tūkst., tikètina, kad 2016-2020 m. kadencijos Seime bus dar daugiau. ${ }^{4}$ Kiekvieną kadenciją priimamų ịstatymų bei kitų teisès aktų projektų nuosekliai daugèjo, o per paskutinę pasibaigusią kadenciją (2012-2016 m.) šie rodikliai buvo patys aukščiausi. Atrodo, kad 2016-2020 m. kadencijos XII Seimas šią kartelę kilstelès dar labiau. Priimtų teisės aktų pirmąkart bus beveik 3 tūkst., o priimtų įstatymų, tikètina, gerokai per 2,1 tūkst., tad galima nusiteikti naujiems Seimo teisèkūros rekordams (žr. 1 pav.).

1996 m. gruodžio 19 d. Lietuvos Respublikos Konstitucinio Teismo nutarimas Nr. 3/96: https://www.lrkt.lt/lt/teismo-aktai/paieska/135/ta419/content

2 Teisékūros tendencijos ir rodikliai Europos Sajungos valstybèse ir Lietuvoje. Atsakingasis redaktorius A. Lukošaitis. Seimo kanceliarijos Parlamentinių tyrimų departamentas, $2015 \mathrm{~m}$. kovo $25 \mathrm{~d}$.

3 Teisékūros procesas. Valstybinio audito ataskaita. $2018 \mathrm{~m}$. kovo $16 \mathrm{~d}$. Nr. VA2018-P-40-62: www.vkontrole.1t

4 Visais atvejais pateikiami 2016-2020 m. Seimo kadencijos VII sesijos pabaigos (2020 m. sausio 2 d.) duomenys. 


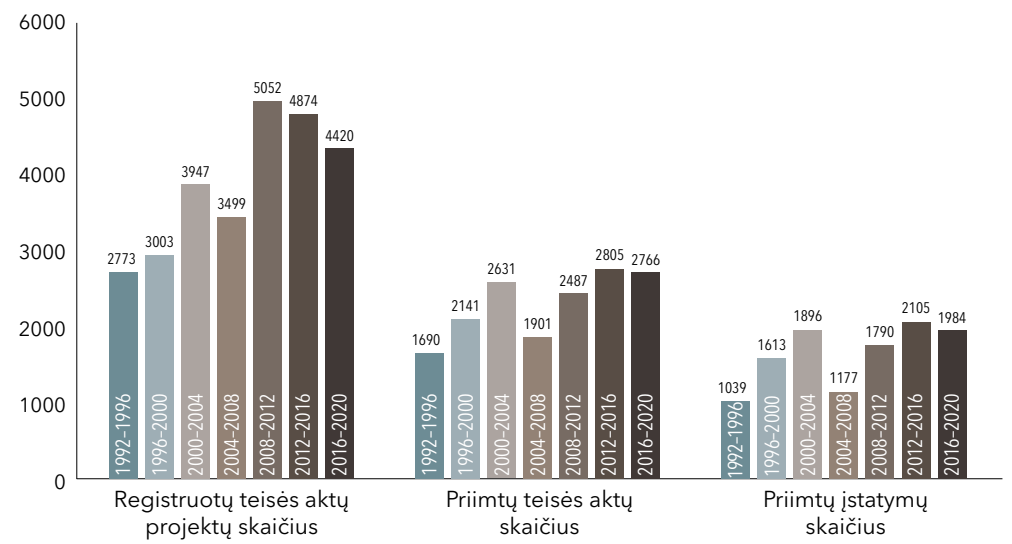

1 paveikslas. Registruotų ir priimtų teisės aktų projektų skaičius. 1992-2020 m. Seimo kadencijos

Anksčiau Seimas priimdavo iki 70 proc. registruotų teisès aktų projektų, per pastarąsias kadencijas šis rodiklis buvo sumažėjęs iki maždaug 50 proc. 2016-2020 m. kadencijos Seime ši tendencija gerejja, tikètina, rodiklis viršys 60 proc. (žr. 2 pav.).

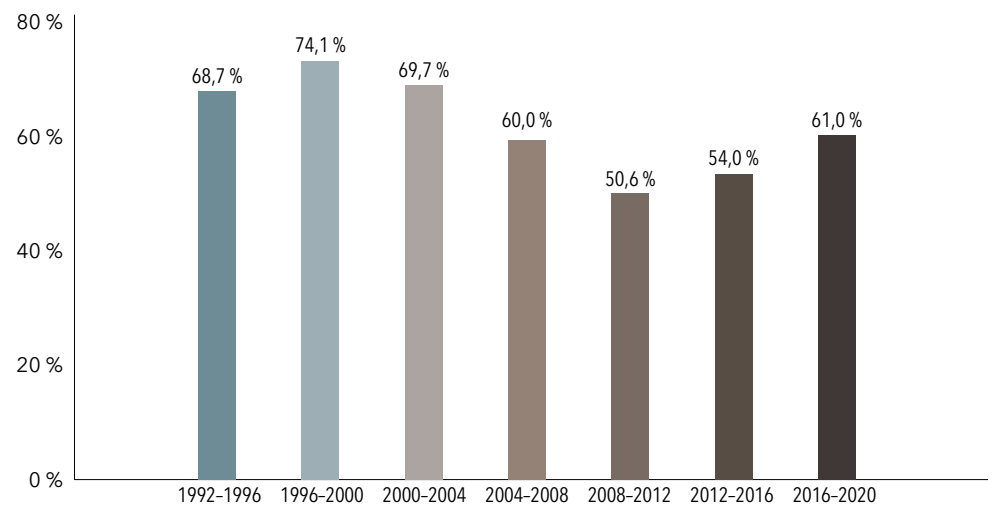

2 paveikslas. Iš registruotų teisès aktų projektų priimta (proc.). 1992-2020 m. Seimo kadencijos 
Galima pastebèti ir priešingą tendenciją - Seimo plenarinių posèdžių teisès aktų projektams svarstyti ir priimti beveik nuosekliai mažejo per visas kadencijas iki paskutinès pasibaigusios. 2016-2020 m. kadencijos Seime, atrodo, ši tradicija nutrūks. Vadinasi, esant tokioms tendencijoms, laiko svarstomiems projektams skiriama vis mažiau, o vidutiniškai per posėdị priimamų teisès aktų projektų tik daugèja (2012-2016 m. Seime iki 7,1 projekto, o 2016-2020 m. Seime jau pasiektas visų laikų aukščiausias vidurkis - 7,5 projekto) (žr. 3 pav.).

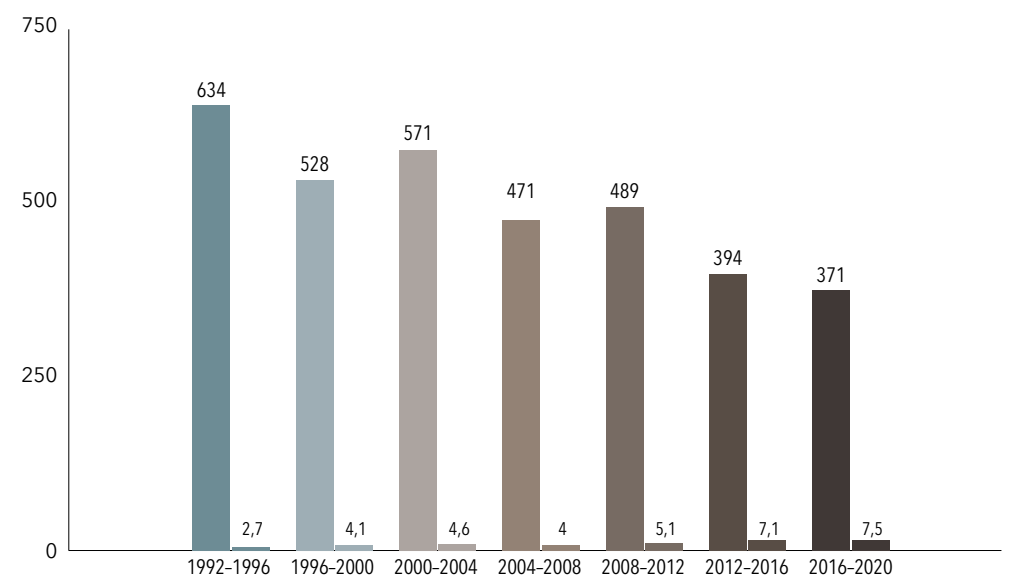

3 paveikslas. Vidutiniškai per Seimo posėdị priimama teisès aktų projektų. $1992-2020 \mathrm{~m}$. Seimo kadencijos (nurodomas plenarinių posėdžių skaičius ir priimtų projektų vidurkis)

Vargu ar tokius Seimo teisèkūros rodiklius galima vadinti racionaliais. Tačiau dar geriau Seimo neracionalumą teisèkūros srityje atskleidžia Seimo narių ir Vyriausybės registruojamų iniciatyvų santykis. Seimo nariai inicijuoja ir registruoja gerokai daugiau projektų nei Vyriausybė, o per kai kurias kadencijas, pavyzdžiui, 2004-2008 m. ir 2012-2016 m., net dvigubai daugiau. Tačiau reikia pabrèžti, kad 
iš visų Seimo narių registruojamų projektų priimama tik apie 50 proc. (kai kurių kadencijų tik iki 40 proc.). O Vyriausybės registruojamų projektų priimama iki 70 ar 80 proc. (žr. 4 pav.).

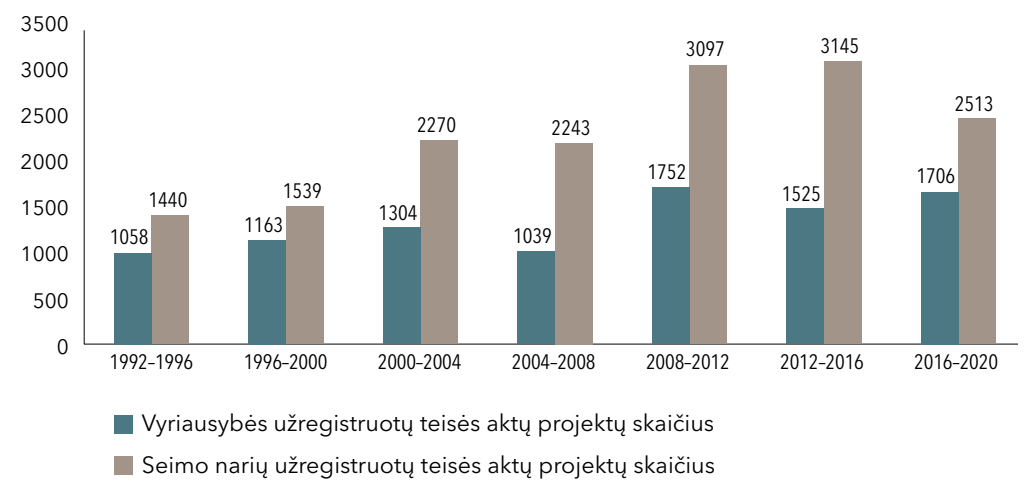

4 paveikslas. Seimo narių ir Vyriausybės užregistruotų teisės aktų projektų skaičius. 1992-2020 m. Seimo kadencijos

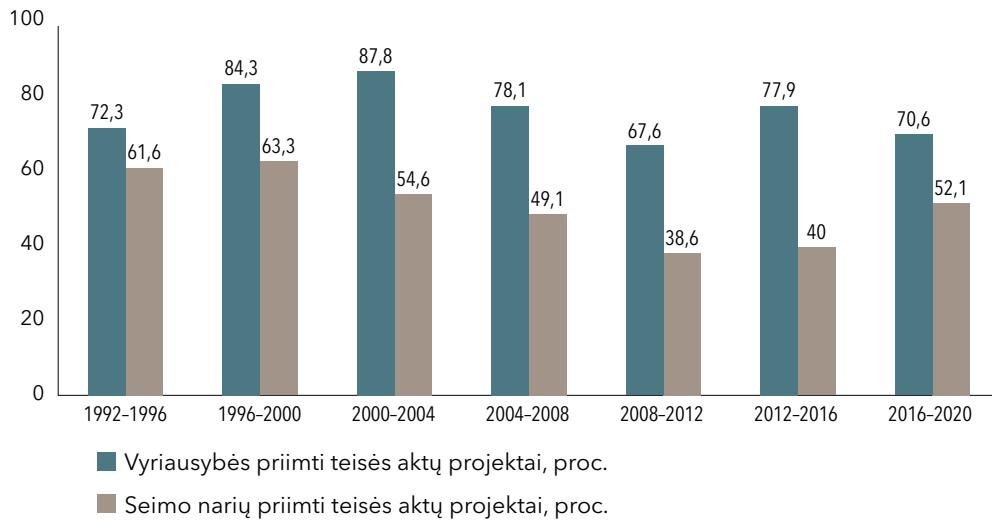

5 paveikslas. Seimo narių ir Vyriausybės registruotų teisės aktų projektų priimta (proc.). 1992-2020 m. Seimo kadencijos 
Vadinasi, Seimas svarsto daugybę teisès aktų projektų, bet galiausiai jie atmetami arba nepriimami. Tai vienas svarbiausių Seimo teisèkūros neracionalumo požymių.

Tačiau bene labiausiai Seimo darbotvarkẻ bei priimamų teisèkūros sprendimų kokybè nukenčia dèl išimtinių teisèkūros (skubos ir ypatingos skubos) taisyklių taikymo. Lietuvos Respublikos Seimo statute šios taisyklès vadinamos skubos ir ypatingos skubos tvarka, kitų šalių parlamentų darbo reglamentuose išimtinès teisèkūros taisyklès vadinamos ịvairiai: skubos tvarka (angl. urgent / urgency procedure), pagreitinta procedūra (angl. fast-track procedure), sutrumpinta procedūra (angl. shortened procedure), išimtine procedūra (anlg. exceptional proceeding), supaprastinta procedūra (angl. summary enactment) ir t. t. Išimtinès teisèkūros taisyklès, kaip žinome, sutrumpina ir supaprastina teisèkūros procesą parlamente, trumpèja sprendimų prièmimo terminai, mažèja teisèkūros etapų ir atsakingų (paskirtų) komitetų reikšmė. Tuo pačiu atkreiptinas dėmesys, kad neretai sprendžiant skubius teisèkūros klausimus taikomos bendrosios teisèkūros taisyklès mutatis mutandis.

Keletą kadencijų Seimas skubos ir ypatingos skubos tvarka priimdavo iki 25 proc. isstatymų projektų, tačiau vadinamajame „kriziniame“ 2008-2012 m. kadencijos Seime šis skaičius šoktelèjo iki neịtikètinos 49,8 proc. aukštumos. Apskritai minètos kadencijos Seimas skubos ir ypatingos skubos tvarka prièmė daugiau kaip 1200 teisès aktų ir įtvirtino teisèkūros praktiką, virtusią prastu ịpročiu ir kitame, 2012-2016 m. kadencijos, Seime, - ir šis tokia pat tvarka issigudrino priimti daugiau kaip 1000 teisès aktų projektų.

Tai reiškė ne ką kita, kaip neatsakingą nepagrịstos teisẻkūros praktikos toleravimą. Ir tik paskutinis, 2016-2020 m. kadencijos, Seimas tokią tvarką pradejo taikyti rečiau, o nuo 2019 m. rudens (VII sesijos) jos taikymą, galima sakyti, apribojo iki minimumo (žr. 6 pav.). 


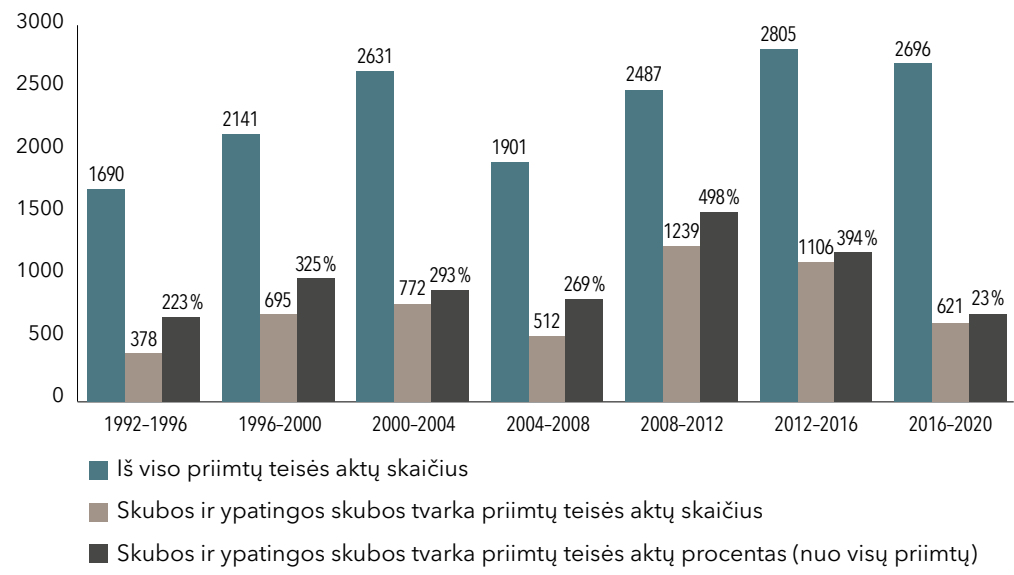

6 paveikslas. Skubos ir išskirtinės skubos tvarka priimti ịstatymų ir kitų teisès aktų projektai. 1992-2020 m. Seimo kadencija

\section{Institucinis ir kultūrinis teisèkūros suvokimas}

2.1. Sistemos transformacija ir paskatos perkrauti teisèkūros darbotvarkę

Nuo 1989 m. trečiosios demokratizacijos bangos užlietoje Vidurio ir Rytų Europoje kokybinis politinių sistemų virsmas susidūrè su vienalaikio „dvigubo“ ar net „trigubo“ perèjimo iššūkiais. ${ }^{5}$ Tai teko ir Lietuvai: tuo pačiu metu atkurti valstybingumą, ịtvirtinti demokratiją ir sukurti laisvos rinkos principais grịstą ekonomiką. Pokyčių mastas - nuo taikios revoliucijos iki totalių esminių politinių reformų. 1990 m. pradžioje demokratiškai išrinktas parlamentas - Aukščiau-

5 Hungtington, S., P. The Third Wave. Democratization in the Late Twentieth Century. Norman, University of Oklahoma, 1991, p. 16; Linz, J., Stepan, A. Problems of Democratic Transition and Consolidation. Baltimore, London: The Johns Hopkins University Press, 1996. 
sioji Taryba-Atkuriamasis Seimas (AT-AS) iškart ir ilgam atsidūrè sisteminių, struktūrinių ir viešosios politikos reformų epicentre. Kitų politinès sistemos segmentų nebuvo ar buvo silpni, tad parlamentas netrukus tapo išskirtiniu demokratizacijos, parlamentarizacijos bei legitimacijos subjektu. Visi šie procesai vyko vienu metu, neịtikètinai intensyviai, neretai komplikuotomis, pavyzdžiui, drastiško ekonomikos nuosmukio ar atviros priešiškų užsienio jẻgų agresijos, sąlygomis.

Dèl laikmečio iššūkių parlamento politinè aplinka tapo labai ittempta, teisèkūros darbotvarkẻ kupina itin sudètingų klausimų. Demokratijos sąlygomis pradejusiam veikti parlamentui teko priimti sudètingus teisèkūros projektus ir sprendimus... dèl paties savęs - jis ne tik kūrè naują institucinį tinklą, bet ir turejjo pats susikurti kaip funkcionali demokratinè institucija. AT-AS darbus nebūtinai lydejo sẻkmè. Pritardami klasikams galètume vaizdžiai pasakyti, kad Lietuvos valstybę pavyko atkurti vos per keletą mènesių, demokratiją konsoliduoti (formaliai) po vadinamojo antrojo valdžios virsmo 1996 m., o laisvos rinkos ekonomikos principus įdiegti per gerą dešimtmetị (formaliai) iki 2000 m. Nepaisant to, pagal G.Sørensen, šalies demokratiją kur kas ilgiau kamavo socialinès ir ekonominès problemos. ${ }^{6}$ Valdžioje besikeičiančių politinių jẻgų netenkino šalies BVP augimo tempai, gyventojų - nepakankami atlyginimai, visi norejo gyventi „kaip Švedijoje“ ir kuo greičiau. Keičiantis valdžioms, dažnai sušlubuodavo vykdomosios politikos tęstinumas, ịstrigdavo struktūrinès reformos, viešosios politikos prioritetų, programų bei projektų igyvendinimas. Visa tai labai veikè politinę ir teisèkūros darbotvarkes.

Antrąji Lietuvos nepriklausomybès dešimtmeti ìsibėgèjusi integracija ì NATO ir europines struktūras konsolidavo politines jègas bei visuomenę dèl šalies strateginès raidos siekių. Šiuo atveju galima kalbèti apie europeizaciją. Plačiąja prasme tai europinio valdymo principų diegimas per vertybių, teisinio reguliavimo taisyklių bei

6 Sørensen, G. Democracy and Democratization. Processes and Prospects in a Changing World. Boulder: Westview Press, 1993, p. 47-60. 
kultūrinių standartų sklaidą bei nacionalinių sistemų institucionalizavimą. Siaurąja prasme europeizacija - vertybių, taisyklių ir standartų įtvirtinimas, pasitelkiant Acquis Communautaire instrumentą. Parlamentui tai reiškè itin intensyvią teisẻkūros darbotvarkę, pirmiausia dèl siekių ES teisés normas perkelti į nacionalinę teisę ir suderinti ją su ES teisynu.

2000-2008 m. ${ }^{7}$, aktyviausiu eurointegracijos laikotarpiu, Seimo veikla teisèkūros srityje iš esmès antrą kartą nuo nepriklausomybès atkūrimo ịgavo naują pagreitị, nors teisèkūros procesui svarbu ne atskiros darbotvarkès dalys, o nuoseklus tęstinumas.

Abiem atvejais parlamento priimti sprendimai buvo susiję su naujos politinès sistemos (arba demokratijos) institucionalizavimu, valdžios galių perskirstymu, nuosavybès santykių reglamentavimu, naujų politinès kultūros vertybių bei sociokultūrinio elgesio standartú ídiegimu. Skirtumas tik tas, kad antruoju, europeizacijos, laikotarpiu dèl parlamento priimtų sprendimų visa politinè sistema patyrė nemenką teisinę akultūraciją. Žinoma, tai turèjo neigiamų padarinių, nes pagreitintas daugybės teisės normų inkorporavimas ị nacionalinę sistemą visuomenès galèjo būti suprastas kaip svetimų normų primetimas ir išprovokuoti jų atmetimą. ${ }^{8}$ Parlamentas ị tokias situacijas neretai reaguodavo daugmaž vienodai - keisdavo ar koreguodavo teisès normas teisèkūros sprendimus priimdamas pakartotinai.

Nesibaigiančios visuotinès reformos, nuolat iš esmès revizuojama viešoji politika ir tęstiniai Seimo teisèkūros darbotvarkès postūmiai (sąlygiškai vadinkime „transformacijos“ (1990-2000 m.) ir „europeizacijos“ (2000-2010 m.) postūmiais) lèmè, kad parlamento darbotvarkè tapo itin intensyvi (angl. overload). Be to, pernelyg dažnai teisès

2000-2004 m. kadencijos Seimas prièmè bemaž 300 (apie 14,5 proc.) vadinamujų „eurointegracinių“ istatymų; 2004-2008 m. kadencijos Seimas prièmè daugiau kaip 200 (apie 18 proc.) ,eurointegracinių“ ịstatymų.

8 Bakševičienè, R. Šiandienès Lietuvos teisès ir kultūros sąsajos galiojančioje Lietuvos teisèje. Teise, 2004, Nr. 52, p. 14-15. 
aktų projektus siekta priimti ar koreguoti teisèkūros procesui taikant išimtines skubos ir ypatingos skubos taisykles. Tai šalyje tik sustiprino ekspertų kritikuojamos „istatymų infliacijos“ (angl. legislative inflation) prielaidas bei pasekmes. Vertinant „europeizacijos“ postūmí, galima sakyti, galutinai buvo įsitikinta, kad parlameno funkcijos nesubalansuotos, o teisèkūra tapusi neadekvačiai išskirtine. Pagaliau visuomenès pasitikejjimas parlamento institucija visiškai sumenko, neretai ekspertų nurodoma, kad tokia padètis susidare dèl nepagrịstų, kaitaliojamų ir nesuprantamų parlamento sprendimų, pirmiausia teisèkūros srityje.

\subsection{Demokratija ir organizuoti interesai teisèkūros procese}

Demokratija nèra vien tik parlamentarizmas, o parlamento funkcija - ne vien teisèkūra. Be to, teisėkūra nebus kokybiška, jeigu nebus tinkamai igyvendinamos kitos parlamento priedermès atstovaujamoji, parlamentinès kontrolès, informavimo, sprendimų legitimavimo ir kitos. ${ }^{9}$

Jaunos demokratijos sąlygomis parlamentai kurị laiką turi išgyventi vadinamąsias „institucinio deficito“ problemas, kai neaišku, kam ir kaip atstovauti. Dar ilgiau užtrunka atstovavimo sektorių interesams, kitaip - funkcinès demokratijos kūrimas. Šie instituciniai atstovaujamosios ir funkcinès demokratijos segmentai - privalomi, norint parlamento teisèkūros lygmeniu užtikrinti efektyvų skirtingų (tautos, sektorių ir pan.) interesų atstovavimą.

Privalomi, nes visų svarbiausia teisèkūros pagrịstumas, informuotumas, atvirumas ir skaidrumas, lygūs proceso dalyvių interesai ir galimybės. Lietuvoje sukurti atstovaujamąją demokratiją, ko gero,

9 R. Packenham priskaičiuoja daugiau kaip tuziną parlamento atliekamų funkcijų. Apie tai žr.: Packenham, R. (1970). Legislatures and Political Development // Kornberg, A., Musolf, L. (eds.). Legislatures in Developmental Perspective. Durham NC: Duke University Press, p. p. 521-582. 
buvo lengviau, nei darnius valstybės ir organizuotų interesų santykius. Bandymai institucionalizuoti lobizmą sukèlè nemažai pasipriešinimo - nuo oligopolinio pliuralizmo, mutuojančio klientelizmo iki atviros politinès korupcijos.

Galima pastebèti, kad Lietuvoje ir politikos, ir teisèkūros darbotvarkès turinị neretai lemia ne demokratijoms būdingi asocijuotų piliečių "politikos tinklų“ (angl. policy networks) interesai ir tikslai. Pagal F. van Waarden, organizuotos politinio spaudimo struktūros dažniau turi verslo „geležinių trikampių“, sektorių korporatyvizmo ar klientelizmo požymių. ${ }^{10}$ Taigi turime organizuotų interesų institucinị potencialą ir siekius ịgyti išskirtinę galią teisèkūrai.

Sunku paneigti, kad Lietuvoje tai pavyksta, neatmestina, kad organizuotos interesų grupès nemažai teisèkūros tikslų pasiekia būtent parlamentinio lobizmo instrumentais. Daugkartiniai „pragmatinių“ mokesčių, viešųjų pirkimų, alkoholio kontrolès, statybų, teritorijų planavimo ir kitų ístatymų keitimai bei pildymai tokias organizuotų interesų poveikio galimybes patvirtina. Neatsitiktinai, nes šiandien svarbiausių Seimo organizacinių struktūrų (frakcijų ir nuolatinių komitetų) ịtaka priimamiems teisèkūros sprendimams akivaizdi. Lobistinių tikslų turinčios organizuotų interesų grupès sèkmès parlamente gali tikètis ir dèl to, kad teisèkūros procesas čia sąlygiškai nesudètingas, o kai kuriais atžvilgiais akivaizdūs ir supaprastinto (redukuoto) proceso bruožai (nedaug teisèkūros etapų, kurị laiką netaikytas kvorumo reikalavimas, dažnos išimtinès skubos taisyklès). ${ }^{11}$ Tai tik skatina organizuotas interesų grupes siekti pragmatinių teisèkūros tikslų parlamentiniu lygmeniu, juo labiau, kad ši procesą ex ante stabdančių institucijų, galima sakyti, Lietuvoje nèra.

${ }^{10}$ Waarden van., F. Dimensions and Types of Policy Networks. European Journal of Political Research, 1992, Nr. 21, p. 29-52; Lukošaitis, A. Lobizmas užsienio šalyse ir Lietuvoje: teisinio reguliavimo ir institucionalizacijos problemos. Politologija, 2011, Nr. 2 (62), p. 4-42.

${ }^{11}$ Lukošaitis, A. Parlamento institucionalizacija ir teisèkūros procesas: Lietuvos atvejis. Vilnius: Vilniaus universiteto leidykla, 2005, p. 173-178. 
2.3. Seimo ir Vyriausybès sąveika kaip teisèkūros darbotvarkès racionalumo sąlyga

Pirmiausia atkreiptinas dèmesys î skirtingų valdžios institucijų sąveiką ir bendradarbiavimą teisèkūros klausimais. Teoriškai būtent su valdžios institucijų bendradarbiavimu teisèkūros srityje betarpiškai siejamas parlamento darbotvarkès racionalumas, t. y. galimybès kvalifikuotai parengti bei priimti $\mathfrak{i}$ darbotvarkę įtrauktus klausimus. Tai priklauso nuo teisèkūros procese dalyvaujančių institucijų galimybių daryti ịtaką parlamento darbotvarkei. Pasak H. Döring, Europos parlamentinèse demokratijose vyriausybès teisèkūros procesą yra tiesiog monopolizavusios, t. y. jos dominuoja ir inicijuojant teisès aktų projektus, ir nagrinejjant juos skirtingose teisẻkūros etapuose, pagaliau ir lemiant galutinių sprendimų prièmimą parlamento plenariniame posėdyje. ${ }^{12}$

Toks parlamento ir vyriausybės galių santykis neretai išreiškiamas hipotetine „90 proc.“ taisykle, reiškiančia, jog būtent tokią dalị teisès aktų projektų vyriausybe inicijuoja, iš kurių maždaug tokia pati dalis priimama. ${ }^{13}$ Ši taisyklè, kaip minèta, hipotetinè, tačiau europinès parlamentinès praktikos statistiniai duomenys iš tiesų patvirtina, jog būtent vykdomoji valdžia parlamentinèse demokratijose lemia parlamento teisèkūros darbotvarkę.

Tačiau Lietuvoje, skirtingai nei Europos parlamentinèse demokratijose, nusistovejo visai kitokios teisèkūros tendencijos. Jeigu europinèje teisèkūros praktikoje galima pritaikyti hipotetinę „90 proc.“ taisyklę, tai Lietuvoje Vyriausybẻ užregistruoja vidutiniškai tik 35,0 proc. teisès aktų projektų, iš kurių priimama vidutiniškai

${ }^{12}$ Döring, H. Fewer Through Presumably More Conflictual Bills: Parliamentary Government Acting as a Monopolist // Döring, H. (ed.). Parliaments and Majority Rule. Frankfurt, New York: Campus Verlag, St. Martin's Press. 1995, p. 593-600.

${ }^{13}$ Olson, D. Democratic Legislative Institutions. A Comparative View. New York: Armonk. 1994, p. 84. 
76,9 proc. Tuo tarpu Seimo nariai užregistruoja vidutiniškai 58,4 proc. teisès aktų projektų, iš kurių vidutiniškai priimama 50,9 proc. Taigi tikrai negalima teigti, kad Vyriausybė lemia formuojamos Seimo teisèkūros darbotvarkès turinị; tiesa, kur kas didesnè jos galia šią darbotvarkę realizuoti, t. y. priimti svarstytus projektus.

Tokios proporcijos Seimo teisèkūros darbotvarkejje atspindi turinio neracionalumą - i ją ịtraukiama pernelyg daug klausimų, jie svarstomi ir galiausiai nepriimami. Iš principo Seimo veiklai teisèkūros srityje būdingas ne santūrumas, o perdètas aktyvumas, kadangi priimama labai daug teisės aktų projektų, jų pataisų ir papildymų. Vyriausybės galimybės pristabdyti šị teisèkūros konvejerị, tarp jų ir politinio poveikio, yra labai ribotos.

\subsection{Seimo nario mandatas ir teisèkūros diskrecijos ribos}

Galima daryti prielaidą, kad aptarti teisèkūros bruožai, be kita ko, sietini ir su Seimo narių mandato, konstitucinių igaliojimų realizavimo niuansais. Lietuvos Respublikos Konstitucijoje itvirtintas laisvo mandato principas, kurio esmé - tautos atstovo laisvè igyvendinti jam suteiktas teises ir pareigas nevaržant šios laisvès rinkejų priesakais, politinių partijų ar visuomeninių organizacijų reikalavimais. ${ }^{14}$ Seimo nario laisvas mandatas - jo teisinio statuso esmé, leidžianti realizuoti suverenias tautos galias teisèkūros srityje. Tačiau laisvas mandatas nèra absoliutus imperatyvas, Seimo nariai nèra visiškai laisvi veikti, jie turi vadovautis Konstitucijos principais, Konstitucinio Teismo doktrina, galiojančiais ir igalinančiais atitinkamai veikti įstatymais. ${ }^{15}$

${ }^{14} 1993$ m. lapkričio 26 d. Lietuvos Respublikos Konstitucinio Teismo nutarimas, bylos Nr. 10: https://www.lrkt.lt/lt/teismo-aktai/paieska/135/ta477/content; $2003 \mathrm{~m}$. gegužè 30 d. Lietuvos Respublikos Konstitucinio Teismo nutarimas, Nr. 21 / 2003 : https://www.lrkt.lt/lt/teismo-aktai/paieska/135/ta285/content; 2004 m. liepos $1 \mathrm{~d}$. Lietuvos Respublikos Konstitucinio Teismo nutarimas, Nr. 04 / 04: https://www. 1rkt.lt/lt/teismo-aktai/paieska/135/ta267/content

15 Sinkevičius, V. Seimas - Tautos atstovybè (konstituciniai pagrindai). Jurisprudencija, 2006, Nr. 9 (87), p. 52-60. 
Laisvas mandatas nereiškia absoliučios teisèkūros laisvès. Kartu negalima neįvertinti, kad parlamentaro darbas bus efektyvus, jeigu jis priklausys parlamento organizacinėms struktūroms, pavyzdžiui, parlamento frakcijai, kurios valios ir sprendimų taip pat neturètų ignoruoti. Laisvo mandato sampratą galima laikyti kriterijumi, kuriuo remiantis galima vertinti šalies politinès kultūros standartus funkcionuojančios parlamentinès demokratijos atžvilgiu. ${ }^{16}$ Kalbant apie Seimo narių teisèkūros veiklą, tikètina, kad jie laisvą mandatą linkę absoliutinti, antraeilę reikšmę teikdami, pavyzdžiui, konstituciniams teisinès valstybės ar atsakingo valdymo principams. ${ }^{17}$

Dèmesio vertas teisès ir politikos santykị tyrinejjusių Ramunès Miežanskienès ir Vytauto Šlapkausko apibendrinimas, kiek tai susiję su teisèkūra, teisès politizavimu ir vice versa. Jie atkreipè dèmesị, kad šiuolaikinès visuomenès juridizacijos mastai yra išaugę, t. y. ir subtiliausiuose socialiniuose santykiuose pasitelkiamos teisès normos. Politika gali būti įteisinama dèl gerovès valstybès siekių ir išaugusio valdymo institucijų skaičiaus, o teisė politizuojama dèl politinių veikejjų interesų ir išskaičiavimų. Anot autorių, Lietuvos atveju akivaizdu, kad teisèkūros prioritetinių sričių pasirinkimą lemia politinių veikèjų valia, ir ypač netolygus teisèkūros pasiskirstymas suponuoja didelị teisès lankstumą greitai kintančios politikos atžvilgiu. Politiniai

16 Žilys, J. Parlamentaro Konstitucinio statuso bruožai demokratijoje. Teisinis istorinis aspektas. Parlamento studijos, 2004, Nr. 2: http://www.parlamentostudijos.lt/Nr3/ Teise Zilys.htm

${ }^{17}$ Lietuvos Respublikos Konstitucinio Teismo nutarimai apie konstitucinị teisinès valstybės principą: $2000 \mathrm{~m}$. gruodžio 6 d. nutarimas Nr. 6/99-23/99-5/2000-8/2000: https://www.lrkt.lt/lt/teismo-aktai/paieska/135/ta348/content; 2002 m. sausio $14 \mathrm{~d}$. nutarimas Nr. 25 / 01: https://www.lrkt.lt/lt/teismo-aktai/paieska/135/ta293/content; 2003 m. sausio 24 d. nutarimas Nr. 20 / 01: https://www.lrkt.lt/lt/teismo-aktai/ paieska/135/ta278/content; apie atsakingo valdymo principą: $2004 \mathrm{~m}$. liepos $1 \mathrm{~d}$. nutarimas Nr. 04 / 04: https://www.lrkt.lt/lt/teismo-aktai/paieska/135/ta267/content; 2015 m. lapkričio 19 d. nutarimas Nr. KT30-N19/2015: https:/www.lrkt.lt/lt/teismo-aktai/paieska/135/ta1527/content; 2016 m. liepos 8 d. nutarimas Nr. KT22-N11 / 2016: https://www.lrkt.lt/lt/teismo-aktai/paieska/135/ta1629/content 
interesai ir vertybės nesunkiai transformuojami ị teisines kategorijas, dèl to Lietuvoje susiformavo, remiantis Mauro Zamboni pateiktu modeliu, atvira teisèkūros sistema, kai politiniai veikèjai teisèkūros iniciatyvas paverčia įrankiu igyvendinti savo interesams. ${ }^{18}$

Nesunku suprasti, kad tokioje atviroje teisèkūros sistemoje itin svarbi tampa įstatymų leidejo, t. y. Seimo nario diskrecija - teisè teisèkūros klausimus spręsti savo nuožiūra (lot. discretio - svarstymas). Atviroje sistemoje teisèkūros subjektų elgesys daug paveikesnis politinėms normoms, politinès kultūros standartams, politiniams interesams, nei uždaroje, kurioje sprendimai susaistyti teisès normų, formalių teisinio reguliavimo taisyklių bei procedūrų. Tačiau nereikètų pamiršti, kad viešajam valdymui negalima taikyti absoliučios diskrecijos laisvès, o diskrecijos teisè neturètų būti aiškinama kaip absoliučiai su niekuo nesaistomas pasirinkimas. ${ }^{19}$ Galima polemizuoti, kokia diskrecija galima teisèkūroje - individuali (Seimo nario), grupinè (nuolatinio komiteto) ar institucinè (parlamento), tačiau šioje srityje, kaip ir kitose, sprendimai turètų būti priimami vadovaujantis teisès aktais. Negana to, šio proceso subjektų elgesys turètų būti labiau suvaržytas politinès kultūros apskritai ir konkrečių parlamentinès kultūros standartų. Tik tokia šių skirtingos prigimties normų - teisès ir politikos - sąveika galètų tapti viena iš esminių sąlygų suteikti santūrumo aktyvistinei teisèkūrai parlamente. Deja, iki šiol Seimo narių diskrecijos ir aktyvumo teisèkūros srityje netramdè nei formaliosios teisès normos, nei parlamentinèje praktikoje nusistovejję sąlygiškai aukšti partinès (parlamento frakcijų) vienybès ir drausmès reikalavimai. ${ }^{20}$

${ }_{18}$ Miežanskienė, R., Šlapkauskas, V. Teisès ir politikos santykio jurisprudenciniai modeliai ir jų taikymo galimybès. Jurispudencija, 2013, Nr. 20 (3), p. 429-450.

19 Bakševičienè, R. Diskrecija vykdant teisėkūrą Lietuvoje. Teise, 2014, Nr. 90, p. 19-30; Bakševičienè, R. Diskrecijos sąvoka Lietuvos viešojoje teisèje. Teise, 2017, Nr. 105, p. 70-83.

${ }^{20}$ Lukošaitis, A. Parlamento institucionalizacija ir teisèkūros procesas: Lietuvos atvejis, ten pat., p. 102-125. 
O sektinų institucinių pavyzdžių nemažai. Teisès ir politikos normų sąveikos, kartu ir parlamento narių diskrecijos suvaržymo pavyzdžiu galètų būti parlamento narių teisèkūros prerogatyvų apribojimai. Dažniausiai tai atliekama:

a) nustatant minimalų ìstatymų leidybos iniciatyvos subjektų skaičių;

b) apibrěžiant laikotarpi, per kurị būtina užregistruoti ir pateikti svarstyti teisès aktų projektus;

c) iškeliant teikiamiems projektams tam tikrus juridinius techninius reikalavimus;

d) nustatant teikiamiems projektams tam tikrus turinio reikalavimus;

e) taip pat numatant, kad teisès aktų projektų nagrinejjimo procedūra gali būti užbaigiama parlamento specializuotuose komitetuose.

Apibendrinti šiuos teisèkūros reikalavimus galètume taip:

- teisès aktų projektų negali inicijuoti pavieniai parlamentarai, tik tam tikras jų skaičius (grupè);

- parlamento nariai savo iniciatyvas turi pateikti per tam tikrą nustatytą laikotarpi;

- registruotiems parlamento narių projektams keliami tam tikri juridinès formos reikalavimai, kad būtų parengiami išbaigti projektai;

- ribojamos parlamento narių galimybès inicijuoti projektus, reglamentuojančius konkrečios srities visuomeninius santykius, pavyzdžiui, biudžeto formavimo ar mokesčių nustatymo;

- parlamento narių įstatymų leidybos iniciatyvos ribojamos nustatant, kad komitetų lygmeniu atmetami tinkamai neparengti projektai. $^{21}$

${ }^{21}$ Ten pat, p. $178-185$. 
Tokiomis ir panašiomis priemonèmis buvo apribota parlamento narių teisèkūros diskrecija daugelyje parlamentinių demokratijų, o jų igyvendinimo praktika toki poreikị tik patvirtindavo.

2.5. Teisékūros planavimas, teisès aktu projekty ekspertizé ir... „skubos nauda velniai gaudo“

Istatymų leidybos procesas yra visuma juridiškai svarbių veiksmų, atliekamų tam tikra logine ir laiko seka, būtinų priimti įstatymui ir svarstyti bei priimti projektus konstituciškai apibrèžtu lygmeniu. ${ }^{22}$ Tačiau teisès aktų projektų kokybès standartai, pirmiausia, kiek yra susiję su ekspertų žinių taikymu teisèkūrai, konstituciniu lygmeniu nèra identifikuoti. Teisèkūros proceso subjektams suteikta diskrecija faktiškai riboja kokybès kriterijų igyvendinimą. ${ }^{23}$

Teisèkūra iš prigimties yra politinių sprendimų prièmimas ir daugeliu atvejų nelinkusi paklusti ekspertų vertinimui. Vien dèl to îstatymų leidèjas ịpareigotas nustatyti tokị reguliavimą, kad būtų atliekamas tinkamas įstatymų projektų ekspertų ịvertinimas, inter allia, dèl neigiamų padarinių, kuriuos gali sukelti nustatytas teisinis reguliavimas. ${ }^{24}$ Ekspertų žiniomis pagrịsti teisèkūros veiksmai galètų tapti siekiamu konstituciškai ịpareigojančiu standartu. ${ }^{25}$

Deja, teisèkūros procese atliekama analizè nepakankama. Jeigu Vyriausybès rengiamiems projektams sudarytose darbo grupèse ekspertų dèmesio tenka daugiau, tai Seimo narių parengti projektai tokio dèmesio tikrai stokoja. ${ }^{26}$ Nepakankamas teisèkūros planavimas

${ }^{22} 1993$ m. lapkričio 8 d. Lietuvos Respublikos Konstitucinio Teismo nutarimas Nr. 8: https://www.lrkt.lt/lt/teismo-aktai/paieska/135/ta475/content

${ }^{23}$ Murauskas, D. Ekspertinis vertinimas teiséküros procese: tarp diskrecijos ir konstituciniu imperatyvu: https://papers.ssrn.com/sol3/papers.cfm?abstract_id $=3410938$

${ }^{24} 2010 \mathrm{~m}$. rugsèjo 29 d. Lietuvos Respublikos Konstitucinio Teismo nutarimas Nr. 35/2008: https://www.lrkt.lt/lt/teismo-aktai/paieska/135/ta182/content

${ }^{25}$ Murauskas, D., ten pat, p. 210.

${ }^{26}$ Bakševičienè, R. Nūdienos teisėkūros proceso reglamentavimo Lietuvoje ir jos veiksmingumo santykis. Teise, 2017 , Nr. 103, p. 147-156. 
ir prioritetų nustatymas, nepakankamas ex ante ir ex post teisès aktų projektų vertinimas, netobulos, formalios poveikio vertinimo ir teisinio reguliavimo stebėsenos metodikos. I šias problemas ne kartą dèmesị atkreipé Ekonominio bendradarbiavimo ir plètros organizacija (OECD) Lietuvai rengiantis narystei šioje organizacijoje, ne kartą apie tai kalbejo ir Lietuvos ekspertai. ${ }^{27}$

Išsamus teisès aktų projektų ekspertų vertinimas turètų apimti ne tik teisinio reguliavimo pagrịstumą, galimas pasekmes, bet ir alternatyvių sprendimų variantus, taip pat galimybes teisinio reguliavimo iš viso atsisakyti. ${ }^{28}$ Žinant svarstomų ir priimamų teisès aktų projektų srautus Lietuvos parlamente, tai būtų itin reikšmingi saugikliai, galintys pristabdyti teisèkūros konvejerị.

Tačiau teisèkūrai beatodairiškai taikomas išimtines (skubos ir ypatingos skubos) taisykles reikètų laikyti viena svarbiausių problemų, atskleidžiančių visą eilę kitų - teisèkūros planavimo, teisès aktų projektų ekspertizès, interesų derinimo ir sprendimų kokybės užtikrinimo. Tokia tvarka daug metų buvo priimama labai daug projektų, be abejo, dèl to nukenčia ir parlamentinių diskusijų, ir priimamų teisèkūros sprendimų kokybé, teisèkūros proceso atvirumas ir skaidrumas. Vertindama Lietuvos pažangą kovojant su korupcija, ị tai atkreipé dèmesį Europos Tarybos kovos su korupcija grupé (GRECO). ${ }^{29}$

${ }^{27}$ Regulatory policy in Lithuania. OECD, 2015: https://read.oecd-ilibrary. org/governance/regulatory-policy-in-lithuania 9789264239340-en\#page6; OECD Regulatory Policy Outlook 2018, OECD Publishing, Paris. https://doi. org/10.1787/9789264303072-en; Lietuvos mokesčiu istatymai: iniciatyvu daug, kokybès trūksta. Lietuvos laisvosios rinkos institutas, Vilnius, 2019: https://www. 1lri.lt/wp-content/uploads/2019/05/Analiz--.-Lietuvos-mokes--i-----statymai-iniciatyv---daug-kokyb--s-tr--ksta.pdf

${ }^{28}$ Limantè, A. Teisèkūros tobulinimo keliu: teisès aktų vertinimas, jo rūšys bei plètotè. Teisés problemos, 2017, Nr. 2 (94), p. 22-42.

${ }^{29}$ Corruption prevention in respect of members of parliament, judges and prosecutors. GRECO, 11, February, 2015: https://rm.coe.int/CoERMPublicCommonSearchServices/DisplayDCTMContent?documentId=09000016806c7660 
2019 m. balandžio 16 d. Lietuvos Respublikos Konstitucinis Teismas prièmè ypač reikšmingą tolesnei teisèkūros plètrai nutarimą, kuriame pabrèžiama, kad teisèkūros procesą supaprastinančios skubos ir ypatingos skubos taisyklès turi būti taikomos atsakingai ir tik aiškiai apibrěžtais, išskirtiniais atvejais. ${ }^{30}$ Dèl naujai suformuluotos konstitucinès doktrinos buvo pakeistos iki tol galiojusios Seimo statuto nuostatos. Sutarta, kad skubos tvarka bus galima tada, kai dèl susidariusių politinių, socialinių, ekonominių ar kitų aplinkybių būtina skubiai nustatyti naują ar pakeisti galiojantị teisinị reglamentavimą siekiant užtikrinti svarbius visuomenès ir valstybès interesus, apsaugoti kitas konstitucines vertybes. $\mathrm{O}$ ypatingos skubos atvejai ịvardinti dar konkrečiau - kai būtina nedelsiant užtikrinti gyvybiškai svarbius visuomenès ir valstybès interesus, t. y. įvedant arba įvedus karo padètị, taip pat ją atšaukiant, skelbiant arba paskelbus mobilizaciją, skelbiant demobilizaciją, priimant sprendimą panaudoti ginkluotąsias pajėgas ginkluoto užpuolimo atveju ir / ar prireikus ypač skubiai vykdyti tarptautinius įsipareigojimus, stichinès nelaimės ar kitomis ekstremaliomis aplinkybėmis, kilus tokiai grèsmei valstybès ar visuomenès saugumui.

Kaip minèta, Seimas, reaguodamas ị naujai suformuluotą konstitucinę doktriną, ne tik pakeitė skubos ir ypatingos skubos taisyklių formuluotes Seimo statute, bet ir iš viso, galima sakyti, nutraukè ju taikymą praktikoje. Tačiau tokị Seimo sprendimą galima vertinti nebent kaip vieną iš daugelio privalomų sprendimų aukštesnei teisèkūros proceso bei priimamų sprendimų kokybei užtikrinti.

Teisèkūros procesui tobulinti reikètų aiškesnių teisèkūros prioritetų ir geresnio planavimo. Prieš keletą metų priimtas Teisèkūros pagrindų i̊statymas padèties negelbsti. Deja, Lietuvoje beveik jokių galimybių kalbèti apie ilgalaikius arba strateginius teisèkūros orientyrus. Vèlgi, kaip nepaminèti nepavejamų kaimynų estų. Jie mus gerokai lenkia ilgalaikio teisèkūros planavimo, projektų ekspertizès, poveikio vertinimo srityje.

${ }^{30} 2019$ m. balandžio 16 d. Lietuvos Respublikos Konstitucinio Teismo nutarimas Nr. KT12-N4/2019: https://www.lrkt.lt/lt/teismo-aktai/paieska/135/ta1926/content 
Prieš kurị laiką Estijos parlamentas buvo patvirtinęs Teisèkūros politikos vystymo iki $2018 \mathrm{~m}$. gaires, o visai neseniai ir vyriausybė pritarè tokioms gairèms iki $2030 \mathrm{~m} .{ }^{31}$ Jose, be kitų dalykų, numatyti ilgalaikès perspektyvos teisèkūros principai, privalomi visoms viešojo sektoriaus institucijoms. Pabrèžiama, kad politinių idejų ir sprendimų igyvendinimo sẻkmę lemia būtent teisẻkūros sprendimų kokybè. Todèl teisèkūrą būtina planuoti, o teisinę sistemą tobulinti taip, kad būtų užtikrinta žmonių gerovè, šalies saugumas ir tarptautinis konkurencingumas. To galima pasiekti tik nuolat peržiūrint galiojančius teisès aktus.

Tarp kitko, estų gairėse numatyta, kad vienokios ar kitokios problemos aukščiausią teisinę galią turinčiu aktu, t. y. įstatymu, turètų būti sprendžiamos tik išimtiniais atvejais, ịsitikinus, kad visos kitos priemonès nerezultatyvios. Tai išties aktualu Lietuvai, kur gajos legalistinès teisèkūros tradicijos - kone visos problemos suprantamos formalizuotai, jas bandoma spręsti vien teisinio reguliavimo priemonėmis pačiu aukščiausiu lygmeniu, - visą naštą perkeliant Seimui.

Iniciatyvų Seimo teisèkūros darbotvarkèje daugybè, tad į antraeilę padèti patenka kiti svarbūs teisèkūros darbai - visuomenè ir jos asocijuotos struktūros ị teisèkūros procesą neịtraukiamos, argumentams teisèkūrai pagrịsti neužtenka laiko, poveikiui vertinti stinga išteklių ir pan. Todèl verta atkreipti dèmesị ir ị estų formalizuotą nusiteikimą parlamente nepriimti teisés aktų projektų, parengtų nesivadovaujant gairèse ịtvirtintais gerosios teisèkūros praktikos principais. Pirmiausia - visuomenès ịtraukimu, teisinio reguliavimo konteksto analize bei teisės aktų projektų pagrindimu ekspertų žiniomis. Tai būtų išties ne taip mažai siekiant teisèkūros sprendimų kokybès ir pakeisti bendrai teisèkūros būklei Lietuvoje.

${ }^{31}$ Annex to Resolution of the Riigikogu. Guidelines for Development of Legislative Policy until 2018: https://www.just.ee/sites/www.just.ee/files/guidelines for development of legislative policy until 2018.pdf; Estonian govt.: Volume of legislative drafting must decrease by $2030 / /$ The Baltic Times, 2019-07-25: https://www.baltictimes.com/estonian_govt_volume_of_legislative_drafting_must_decrease_by_2030/ 


\section{Apibendrinimas}

1. Atkūrus Lietuvos nepriklausomybę, vienos iš svarbiausių šalies institucijų Seimo veikla teisèkūros srityje buvo ir išlieka itin aktyvi, o teisèkūros darbotvarkèje gausu įstatymų ir kitų teisès aktų projektų. Seime registruojama labai daug teisèkūros iniciatyvų, bet didelè dalis jų lieka neigyvendintos. Vyriausybė užregistruoja gerokai mažiau teisès aktų projektų nei Seimas, bet užregistruotųjų Vyriausybès priimama daugiau. Politikos mokslų teorijoje tokia tendencija apibūdinama kaip vyriausybès nekontroliuojama [parlamento] teisèkūros darbotvarkè, ir tai pripažǐstama esmine jos neracionalumo problema.

2. Lietuvos parlamentas teisèkūros srityje prioritetą teikia ne kokybiniams, o kiekybiniams veiklos rodikliams. Pagal priimamų teisès aktų projektų skaičių ir išimtinių skubos taisyklių taikymą teisẻkūros procese mūsų Seimas yra išskirtinis tarp Europos parlamentų. Per pastarąsias dvi pasibaigusias kadencijas (2008-2012 ir 2012-2016 m.) skubos ir ypatingos skubos tvarka buvo priimta gerokai daugiau nei po tūkstantị įstatymų ir kitų teisès aktų projektų arba nuo 40 iki 50 proc. visų projektų. Tik 2019 m. balandžio 16 d. Lietuvos Respublikos Konstitucinis Teismas atkreipé dėmesị i išimtinių skubos taisyklių taikymo teisèkūrai nepagrịstumą ir žalingumą, tad 2016-2020 m. kadencijos Seimas jų taikymo iš esmès atsisakè.

3. Perdètą Seimo aktyvumą ir ịtemptą teisèkūros darbotvarkę lèmè sudètingas laikmetis - pirmiausia reikejjo įtvirtinti valstybingumą ir pertvarkyti sistemą, paskui - imtis struktūrinių reformų ir europeizuoti sistemą. Demokratizacijos, viešosios politikos ir struktūrinių reformų nesèkmès, taip pat ir objektyviai nepasvertas Acquis Communautaire spaudimas kiekvieną naujai išrinktą Seimą verte peržiūrèti teisèkūros sprendimus. Teisèkūros procesui parlamente neskaidrumo suteikè gerai organizuotos interesų grupès, susibūrusios neinstitucionalizuoto parlamentinio lobizmo priemonemis siekti siaurų egoistinių tikslų. Tai kiek destabilizavo teisinę sistemą ir redu- 
kuotą teisèkūros procesą parlamente ir neskatino visuomenès pasitikèti parlamento institucija.

4. Seime registruojamų, svarstomų ir (ne)priimamų teisès aktų projektų santykis atspindi ir kitą Lietuvos teisèkūros problemą: svarbiausių teisèkūros subjektų Seimo ir Vyriausybės bendradarbiavimas teisèkūros klausimais nepakankamas. Seimo teisèkūros darbotvarkès turinị dažniau lemia ne Vyriausybė, kaip ịprasta Europos parlamentinėms demokratijoms, o Seimo nariai. Vadinamosios atviros teisèkūros bruožų turinčioje Lietuvos sistemoje tampa itin svarbūs įstatymų leidèjo, t. y. Seimo narių interesai ir diskrecija - teisè teisèkūros klausimus spręsti savo iniciatyva ir nuožiūra. Atkreiptinas dėmesys, kad iki šiol Seimo narių diskrecijos ribos teisèkūroje suprantamos kaip lanksčios, o šios teisès realizavimo neribojo nei formalios teisès normos, nei parlamentinèje praktikoje nusistovèję sąlygiškai aukšti partinès vienybès ir drausmès reikalavimai.

5. Lietuvos teisèkūroje vyrauja legalistinis požiūris - kone visas visuomeninių santykių problemas bandoma spręsti teisinio reguliavimo priemonėmis pačiu aukščiausiu, t. y. ịstatymų lygmeniu. Lietuvoje nèra tinkamo teisès aktų projektų ekspertų vertinimo. Vyriausybės parengtiems teisès aktų projektams darbo grupèse ekspertų dėmesio skiriama daugiau, o Seimo narių parengtiems projektams jo nepakanka. Ekspertai turètų ịvertinti ne tik teisès aktų projektų teisinio reguliavimo pagrịstumą, galimas pasekmes, bet ir alternatyvių sprendimų variantus bei galimybes teisinio reguliavimo apskritai atsisakyti. Teisèkūroje per mažai dèmesio skiriama prioritetams apibrèžti, perspektyvai planuoti, poveikiui vertinti ir teisinio reguliavimo stebèsenai, visuomenei ịtraukti ị teisèkūros procesą ikiparlamentinèse teisèkūros stadijose. Sektinas pavyzdys - kolegų iš Estijos, patvirtinusių ilgalaikès perspektyvos teisèkūros politikos gaires, reikalaujančias, kad teisinio reguliavimo problemos įstatymų lygmeniu būtų sprendžiamos tik išimtiniais atvejais, kai visos kitos priemonès neduoda laukiamų rezultatų. 


\title{
FEATURES OF LEGISLATION IN LITHUANIA: INSTITUTIONAL AND CULTURAL FRAGMENTS OF UNDERSTANDING THE ISSUES
}

\author{
Alvidas Lukošaitis
}

\section{Summary}

Keywords: legislation, legislative order, agenda of legislation, expertise of legal acts, urgency / fast-track procedure, legislative discretion, planning of legislative agenda.

This article analyzes the legislative process on a parliamentary level. It is argued that the views of members of the Seimas and unconstructive interaction between legislative authorities cause part of the legislative problems in the country.

The Seimas of the Republic of Lithuania has been hyperactive in legislation for the most part of the independence, while the legislative agenda is usually overloaded by laws and other legislative projects. The Parliament prioritizes quantitative performance indicators over qualitative performance indicators in the legislative process. The hyperactivity of the Seimas and overloaded legislative agenda are caused by difficult circumstances of that era. Initially, it was more related to the goals of consolidating the statehood and reforming the system, later - to the goals of structural reforms and europeanization.

There is no proper expert assessment of draft legal acts in Lithuania. It should include not only the validity of the legal regulation, possible outcomes but also the alternative solutions (including the possibility of rejecting the legal regulation in general). Additionally, there is little attention to purification of the priorities, longterm planning, impact assessment, the monitoring of legal regulation and public involvement in the pre-parliamentary stages of legislative process.

The ratio of registered, considered and (not) adopted drafts indicates another legislative issue in Lithuania - the cooperation between the main legislative subjects (the Seimas and the Government) is insufficient regarding legislative issues. Also, it is important to note that the legalistic approach is prevailing in Lithuanian legislative culture - the vast majority of public relations' problems are tried to be solved by the legal regulation means and by the most supreme level the law.

Iteikta $2020 \mathrm{~m}$. vasario $27 \mathrm{~d}$. 